\title{
Isolation and identification of thermophilic amylolytic bacteria from Likupang Marine Hydrothermal, North Sulawesi, Indonesia
}

\author{
ELVY LIKE GINTING ${ }^{1, \vartheta}$, LETHA L. WANTANIA ${ }^{2}$, EMMA MAUREN MOKO ${ }^{3}$, REINY A. TUMBOL ${ }^{1}$, \\ MAYSE S. SIBY ${ }^{1}$, STENLY WULLUR ${ }^{1}$ \\ ${ }^{1}$ Faculty of Fisheries and Marine Science, Universitas Sam Ratulangi. Jl. Kampus Unsrat, Manado 95115, North Sulawesi, Indonesia. \\ Tel./fax.: +62-431-868027, `email: like.ginting@unsrat.ac.id \\ ${ }^{2}$ Faculty of Mathematics and Natural Sciences, Bonn University. D-53012 Bonn, Germany \\ ${ }^{3}$ Department of Biology, Faculty of Mathematics and Natural Science, Universitas Negeri Manado. Jl. Raya Tondano, Minahasa 95618, North Sulawesi, \\ Indonesia
}

Manuscript received: 1 April 2021. Revision accepted: 24 May 2021.

\begin{abstract}
Ginting EL, Wantania LL, Moko EM, Tumbol RA, Siby MS, Wulur S. 2021. Isolation and identification of thermophilic amylolytic bacteria from Likupang Marine Hydrothermal, North Sulawesi, Indonesia. Biodiversitas 22: 3326-3332. The aims of the research were to isolate and identify the amylase-producing thermophilic bacteria from Likupang Marine Hydrothermal, North Sulawesi, Indonesia. The bacteria were characterized based on the colony and cell morphology and subsequently screened for their amylase activities. The bacterial isolates were identified based on 16S rRNA gene sequences. There were 12 thermophilic bacteria isolates from Likupang Marine Hydrothermal that were able to produce amylase. Two selected isolates (L3 and L9) had an amylolytic index value in the range of 3.04-3.52 at $55^{\circ} \mathrm{C}$. The colonies of $\mathrm{L} 3$ and $\mathrm{L} 9$ are circular, and they are Gram positive, rod-shaped, and motile bacteria. Based on the 16S rRNA gene sequences and phylogenetic tree analysis showed that L3 was closely related to Bacillus caldotenax with $93 \%$ similarity while L9 had 99\% similarity to B. caldotenax. Hence, we identified L3 isolate as Bacillus sp. strain L3 and L9 isolate as B. caldotenax strain L9. Both of these bacteria were grouped as Geobacillus thermoleovorans.
\end{abstract}

Keywords: Amylase, Bacillus, identification, Likupang, thermophilic

Abbreviations: BLAST: Basic local alignment search tool, DDH: DNA-DNA hybridization, DNA: deoxyribonucleic acid, PCR: polymerase chain reaction, TMMB: thermus medium modified broth, TMMA: thermos medium modified agar, 16S rRNA: 16 Svedberg ribosome-ribonucleic acid, VP: Voges-Proskauer

\section{INTRODUCTION}

Bacterial populations are widespread in various environmental conditions, including many places with extreme conditions, such as $\mathrm{pH}$, salinity, and temperature. Bacteria that can survive in high temperatures are known as thermophilic bacteria. One of the notable abilities of thermophilic bacteria is to produce enzymes that are stable at high temperatures, and the enzymes catalyze their chemical reactions at high speed at high temperatures (Singh et al. 2011; Mohammad et al. 2017). Moreover, thermophilic bacteria are the ideal choice for producing thermostable enzymes, which makes them interesting research subjects. In particular, the thermostability of their cell components in highly elevated temperatures has led to their extensive use in various biotechnological and industrial applications (Raddadi 2015; Charbonneau et al. 2012). They were very useful in industrial application because they have several advantages, i.e., high growth rate, accelerate fermentation processes two to three times over those with mesophilic producers, reduced risk of microbial contamination, higher diffusion rate, and mass turnover, reduced the viscosity of culture liquids, and improved solubility of polymeric substrates and fats that are usually insoluble compounds (Kambourova 2018). The thermostability of cell components in high and elevated temperatures is the reason for their extensive use in industrial applications and multiple biotechnological (Raddadi 2015; Charbonneau et al. 2012).

In high-temperature bioprocessing, the enzymes produced by thermophilic bacteria can reduce risk of contamination, improve solubility of substrates (i.e., lignocellulosic biomass), lower chances of phage infection, and reduce cooling costs. The cooling cost specifically are reduced due to greater temperature differential between the fermenter and the ambient air, which is the ultimate heat acceptor with the addition of continuous recovery of volatile chemical products directly from fermentation broth. (Frock and Kelly 2012; Keller et al. 2014). One of the enzymes produced by thermophilic bacteria is amylase which has an important role in biotechnological studies and the world enzyme market (25\%-33\%) (Nguyen et al. 2002). Amylase hydrolyze starch to produce maltose, glucose, malto-oligosaccharides, and various $\alpha$-limit dextrincontaining $\alpha$ (1-6) bonds. They have a spacious range of uses in pharmaceutical, cosmetic, agricultural industries, food, and nutritional processes (Satrimafitrah et al. 2019; Gazali and Suwastika 2018; Luang-In et al. 2019; De Souza and Magalhaes 2010). 
Some hot springs in Indonesia are sources of thermophilic bacteria that could produce amylase (Gazali et al. 2018; and Ardhi et al. 2020). Thermophilic bacteria can also be found in shallow water hydrothermal and seabed hot springs. Marine hydrothermal spots can be discovered in many places throughout Indonesia including North Sulawesi. One of the marine hydrothermal in North Sulawesi is in Likupang. A study by Myung-Ji et al. (2012) revealed microbial diversity in Likupang based on the $16 \mathrm{~S}$ rRNA gene sequence. One hundred and five representative clones from this thermal vent showed that the highest proportion was $\gamma$-Proteobacteria $(33.3 \%)$, followed by Bacteroidetes $(27.6 \%)$ and unclassified bacteria group $(20 \%)$. The minor groups were affiliated to Firmicutes $(7.6 \%)$ and $\alpha$-Proteobacteria $(4.8 \%)$. On the other hand, the research on amylase-producing thermophilic bacteria from this area has not been reported yet. Therefore, the present study was carried out to isolate and identify the thermophilic amylolytic bacteria from Likupang Marine Hydrothermal, North Sulawesi, Indonesia.

\section{MATERIALS AND METHODS}

\section{Sampling}

Marine water samples were collected from 3 points on the hot spring location at East Likupang beach, North Minahasa District, North Sulawesi Province, Indonesia (1'39'54.87"N, 12506'19.41"E) (Figure 1). They were taken directly using sterile bottles and placed in cool box. Samples were carried to the laboratory for bacteria isolation and further testing. The temperatures during the sampling were measured on site using glass thermometer.

\section{Culture and bacteria isolation}

Twenty $\mu \mathrm{L}$ of marine water sample was inserted into 5 $\mathrm{mL}$ of Thermus Medium Modified Broth (TMMB-0.01\%

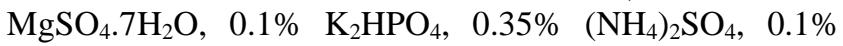
$\mathrm{NaCl}, 0.05 \%$ Yeast extract, $0.05 \%$ peptone) and incubated at $55^{\circ} \mathrm{C}$ for $24-48$ hours. As much as $0.1 \mathrm{~mL}$ of cultured broth was spread onto TMMA (TMMB + $2 \%$ Agar) using L-glass followed by incubation at $55^{\circ} \mathrm{C}$ for $24-48$ hours. Single growing colonies with different morphological characteristics (e.g., color, colony, growth shape, and edges) were individually isolated, which were then developed on new TMMA, and observed more carefully for their morphology characteristics.

\section{Screening the thermopiles bacteria producing amylase}

The single colony of the bacterium was spotted onto the surface of TMMA containing $2 \%$ of amylum on a plate, followed by incubation at $55^{\circ} \mathrm{C}$ for $24-48$ hours. The ability of the bacteria to produce amylase was observed by the appearance of a clear zone around the colony by flooding it with Lugol's iodine solution (w/v) (1\% iodine in $2 \%$ potassium iodide). The clear zone and colony diameters were estimated using a caliper rule (Poletto et al. 2018). The amylolytic index value of each isolate was determined based on the ratio of clear zone diameter and diameter of a colony (Soy et al. 2019).

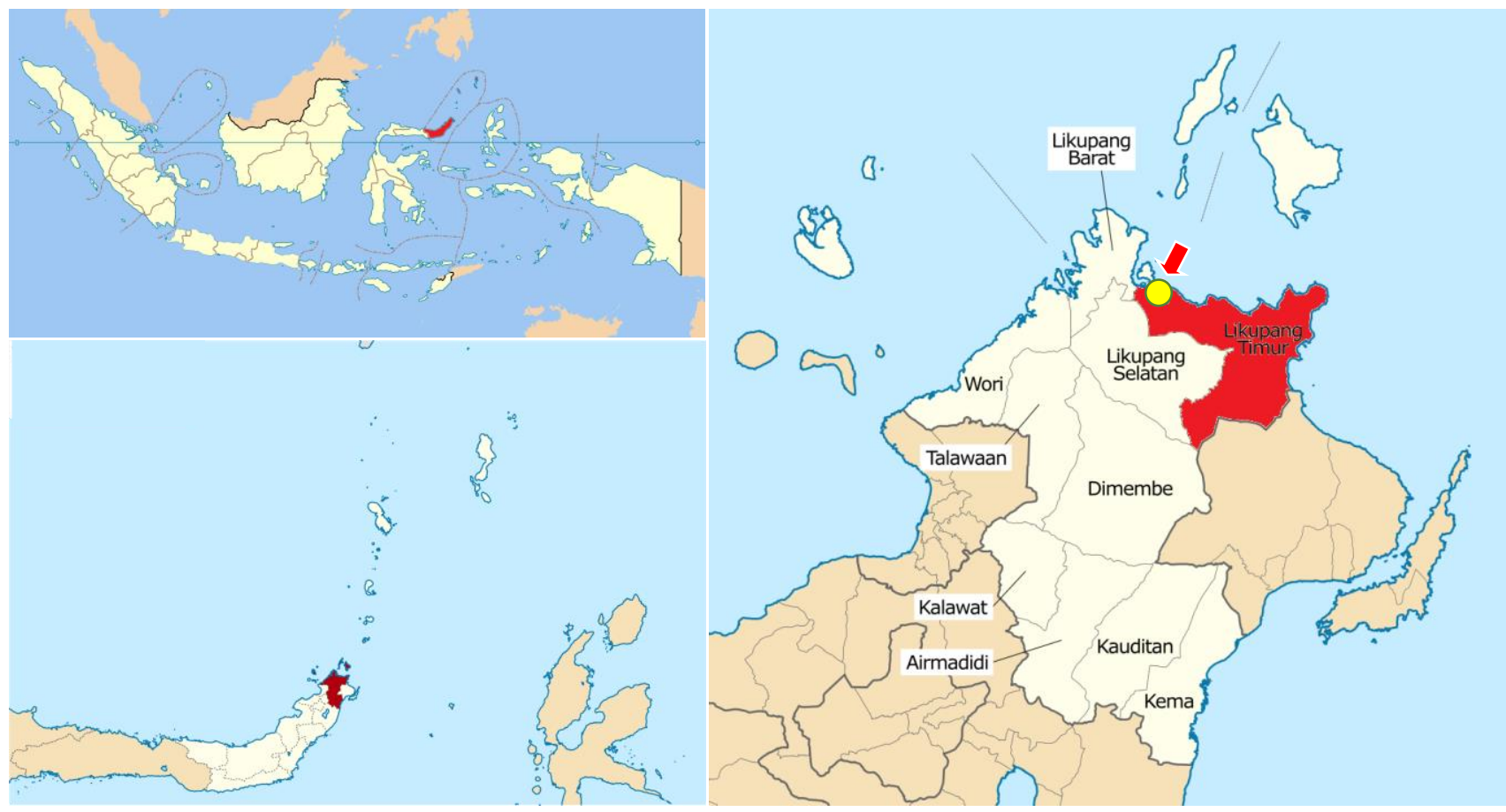

Figure 1. The map of North Minahasa District, North Sulawesi Province, Indonesia. The sampling location is in the Likupang Marine Hydrothermal, East Likupang Sub-district as indicated by an arrow 
Identification of the active amylolytic thermophilic bacteria Morphological and physio-biochemical characterization

Preliminary identification of the bacterial isolates with amylolytic activity was carried out based on morphological and physio-biochemical characteristics. Morphological characteristics observed were Gram-stain (Thairu et al. 2014), motility of bacteria, and biochemical properties. Bacterial motility was determined using semi-solid media, while biochemical properties included parameters of carbohydrate utilization, gas production, sugar fermentation (glucose, lactose, sucrose, maltose), indole production, methyl red, Voges-Proskauer (VP), citrate utilization, and $\mathrm{H}_{2} \mathrm{~S}$ production.

\section{Molecular identification and phylogeny}

Identification of bacterial isolates was confirmed by 16S rRNA gene analysis. Genomic DNA from each sample was prepared based on the protocol in the QIAprep Miniprep kit (Qiagen Hilden, Germany). The genomic DNA was used as the template for PCR amplification of $16 \mathrm{~S}$ rRNA gene region with the universal primer pair (Integrated DNA Technologies-IDT, Singapore) 8F (5'. AGAGTTTGATCCTGGCTCAG-3') and 1492R (5'TACCTTGTTACGACT-3') (Zhang et al, 2018). Amplifications were carried out with $4 \mu \mathrm{l}$ master mix (5× HOT FIREPol Blend Master Mix, Solis BioDyne, Estonia),

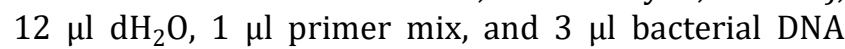
(total volume $20 \mu \mathrm{l}$ ). The PCR steps consist of predenaturation at $95^{\circ} \mathrm{C}$, for 30 seconds; annealing at $52^{\circ} \mathrm{C}$, for 30 seconds; and elongating at $72^{\circ} \mathrm{C}$, for 30 seconds. The PCR process consists of 35 cycles. After that, the phase post-PCR starts at $72^{\circ} \mathrm{C}$ for 10 minutes, and the stop PCR at $4^{\circ} \mathrm{C}$. Nucleotide bases of the PCR products were then separated using $1 \%$ agarose gel in electrophoresis at 30-40 $\mathrm{V}$ and 28-29 mA, with a $10.000 \mathrm{bp}$ DNA ladder as a marker (Solis BioDyne, Estonia). The PCR products were subsequently sent for nucleotide sequence to a DNA gene analysis service at First-Base Co., Selangor, Malaysia.

DNA sequences of the $16 \mathrm{~S}$ rRNA gene quality were assessed using Sequence Scanner version 2.0 Software (Applied Biosystem) and the sequence traces were trimmed, assembled, and edited using MEGA Version 7. The sequences were subjected to BLAST using rRNA type strains/prokaryotic16S_ribosomal RNA (bacteria and archaea) database setting in The National Center for Biotechnology Information (http://www.ncbi.nlm.nih.gov/). Selected sequences from the NCBI database were aligned using CLUSTX (http://www.clustal.org/). Gaps and the 5' and 3' ends of the alignment were edited using BioEdit sequence alignment editor software version 7.2.5 (http: //www.mbio.ncsu.edu/bioedit/page2.html). The phylogenetic tree was developed by neighbour-joining in MEGA Version 7 (Kumar et al. 2016).

\section{RESULTS AND DISCUSSION}

In total, 12 thermophilic bacteria were successfully isolated from Likupang Marine Hydrothermal, which were able to grow at $55^{\circ} \mathrm{C}$. All of these isolates had an amylolytic index at TMMA containing 2\% of amylum. There were two isolates (L3 and L9) that have the highest amylolytic indexes were further identified.

L3 and L9 had different morphological and physiobiochemical characteristics (Table 1). The ability of these bacteria to degrade amylum is indicated by the appearance of a clear zone around the colonies on the media containing $2 \%$ amylum at $55^{\circ} \mathrm{C}$ (Figure 2). The average amylolytic index of L3 and L9 were 3.04 and 3.52, respectively. The more amylase, the wider the clear zone due to the degrading of amylum on the medium which renders enhancement the amylolytic index.

The 16S rRNA gene of the two thermophilic amylolytic bacteria was successfully amplified and showed a DNA band at around 1500 bp (Figure 3). Amplification 16S rRNA sequences of bacteria were established on $\sim 1500 \mathrm{bp}$ amplicon (Akihary et al. 2020; Wullur et al. 2020; Ginting et al. 2019; Wantania et al. 2019). Furthermore, after sequence 16S rRNA was trimmed, assembled, and edited, the 16S rRNA gene sequence of L3 was 936 bp and L9 was $1120 \mathrm{bp}$.

Based on 16S rRNA gene sequence data of the bacterial isolates which were analyzed using rRNA typestrains/ prokaryotic16S_ribosomal RNA database in NCBI showed that L3 was closely related to Bacillus caldotenax (93\% similarity), and L9 to B. caldotenax (99\% similarity) (Table 2). Both 16S rRNA genes had the same as the top five hits against Nucleotide BLASTed, which were B. caldotenax, Geobacillus kaustophilus, and Geobacillus thermoleovorans species. According to Nazina et al. (2001) B. thermoleovorans, B. kaustophilus, and Bacillus thermocatenulatus, which also included Bacillus caldolyticus, Bacillus caldovelox, and $B$. caldotenax should be combined into one species, namely G. thermoleovorans as shown in Table 2. This grouping was based on the level of DNA-DNA reassociation values. It was also consistent compared to the phylogenetic data of Nazina et al. (2005) and Zeigler (2005). Moreover, Aliyu et al. (2016) proposed for the strains of $G$. kaustophilus and G. thermoleovorans to be referred to as $G$. thermoleovorans species.

Table 1. Physio-biochemical characteristics of the L3 and L9 thermophilic bacteria

\begin{tabular}{lcc}
\hline \multicolumn{1}{c}{ Characteristics } & L3 & L9 \\
\hline Cell shape & Rods & Rods \\
Colony shape & Circular & Circular \\
Colony color & Cream/Yellow & Cream/Yellow \\
Gram stain & + & + \\
Motility & + & + \\
Carbohydrate utilization & - & - \\
Gas production & - & - \\
Glucose & - & - \\
Lactose & + & + \\
Sucrose & + & + \\
Maltose & + & + \\
Indole Production & + & - \\
Methyl red & - & - \\
Voges-Proskauer (VP) & - & + \\
Citrate Utilization & - & - \\
H2S Production & - & - \\
\hline
\end{tabular}






Figure 2. Bacterial isolates were spotted on TMMA containing $2 \%$ amylum. The clear zone around the bacteria indicated the amylum degradation by amylase that produced the bacteria.

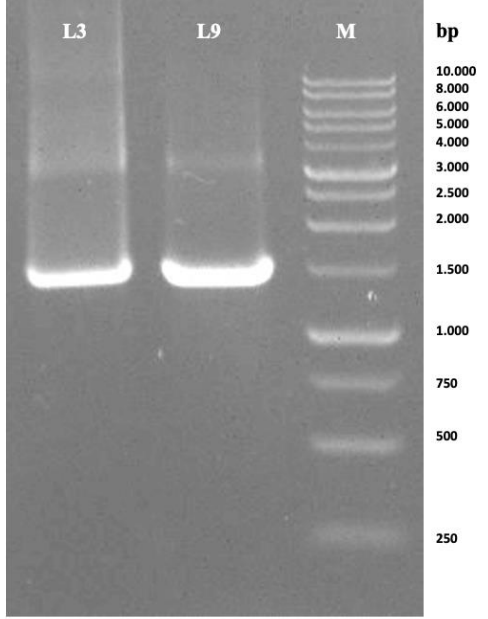

Figure 3. The amplified 16S rRNA gene of the two isolates amylase-producing thermophilic bacteria in the $1 \%$ agarose gel electrophoresis, using 10.000 bp DNA ladder as a marker.

Table 2. Top five nucleotide blast hits of 16S-rRNA gene of the bacterial using rRNA typestrains/prokaryotic16S_ribosomal RNA (bacteria and archaea) database setting in the NCBI GenBank

\begin{tabular}{|c|c|c|c|c|c|c|}
\hline Isolates & Taxonomy & Species \& accession number & Score & $\begin{array}{l}\text { Query } \\
\text { cover }\end{array}$ & E-value & Identity \\
\hline \multirow[t]{9}{*}{ L3 } & Bacillales & & & & & \\
\hline & Bacillaceae & & & & & \\
\hline & Geobacillus & & & & & \\
\hline & G. thermoleovorans group & & & & & \\
\hline & & Bacillus caldotenax, NR 126321.1 & 898 & $98 \%$ & 0.0 & $93.48 \%$ \\
\hline & & Geobacillus thermoleovorans, NR 115286.2 & 896 & $84 \%$ & 0.0 & $93.32 \%$ \\
\hline & & Geobacillus kaustophilus, NR115285.2 & 893 & $90 \%$ & 0.0 & $93.32 \%$ \\
\hline & & Geobacillus kaustophilus, NR 114089.1 & 893 & $90 \%$ & 0.0 & $93.16 \%$ \\
\hline & & Geobacillus thermoleovorans, NR 036985.1 & 893 & $90 \%$ & 0.0 & $93.32 \%$ \\
\hline \multirow[t]{9}{*}{ L9 } & Bacillales & & & & & \\
\hline & Bacillaceae & & & & & \\
\hline & Geobacillus & & & & & \\
\hline & G. thermoleovorans group & & & & & \\
\hline & & Bacillus caldotenax, NR 126321.1 & 1336 & $99 \%$ & 0.0 & $99.32 \%$ \\
\hline & & Geobacillus thermoleovorans, NR 036985.1 & 1336 & $99 \%$ & 0.0 & $99.32 \%$ \\
\hline & & Geobacillus kaustophilus, NR 115285.2 & 1336 & $99 \%$ & 0.0 & $99.32 \%$ \\
\hline & & Bacillus caldotenax, NR 126322.1 & 1334 & $99 \%$ & 0.0 & $99.19 \%$ \\
\hline & & Geobacillus thermoleovorans, NR 115286.2 & 1328 & $99 \%$ & 0.0 & $99.05 \%$ \\
\hline
\end{tabular}

The phylogenetic analysis of L3 and L9 were presented in Figure 4. The phylogenetic analysis showed the relation between L3 and L9 with their close homologs. All the closed related homologs of the rRNA typestrains/ prokaryotic16S_ribosomal RNA (bacteria and archaea) registered in The National Center for Biotechnology Information (NCBI) were used in the construction of the phylogenetic tree to obtain their evolutionary origin. The phylogenic analysis result showed that L3 and L9 were at different branching. It indicated that L3 and L9 were different bacterial strains. The L3 isolate has 93\% similarity with $B$. caldotenax which revealed that there was a different strain of L3 with $B$ caldotenax. However, in determining an isolate as a new strain, a certain analysis should be done along with 16S rRNA analysis. Therefore, the result of this research indicated that L3 is a genus Bacillus.

The taxonomy of the genus Bacillus showed that the bacteria species were members of Bacillus rRNA Group 5 (Cihan 2012). Several members of Group 5 were reclassified into the new genus Geobacillus based on a combination of $16 \mathrm{~S}$ ribosomal RNA (rRNA) sequence analysis, fatty acid composition, and DNA-DNA hybridization (DDH) (Dinsdale et al. 2011). The morphological characteristics of L3 and L9 showed the characteristics of Bacillus/Geobacillus thermophile. L3 and L9 were Gram-positive, rod-shaped and motile. According to Nazina et al. 2001; Cho and Chung 2020, Bacillus/ Geobacillus has the characteristics of Gram-positive, rod- 
shaped and motile, heat resistance and the optimum growth temperatures at $55-65^{\circ} \mathrm{C}$.

The temperatures at the sampling location in Likupang Marine Hydrothermal, North Sulawesi, Indonesia were 65$70^{\circ} \mathrm{C}$ which strongly supports the growth of the Geobacillus. $G$. thermoleovorans from the volcanic geothermal environment have morphological characters as a cream colony, Gram-positive motile, and rod-shaped. These characteristics of $G$. thermoleovorans were similar to L3 and L9 characteristics. Therefore, we conclude that L9 is B. caldotenax and L3 is Bacillus sp. Both of these strains were members of the $G$. thermoleovorans group. Hence, we identified L3 as Bacillus sp. strain L3 and L9 as B. caldotenax strain L9. B. caldotenax were also successfully isolated from Sumber Air Panas Gedongsongo, Indonesia (Nihaya et al. 2013) and shallow hydrothermal vents of Panarea Island, Italy (Gugliandolo et al. 2012).

$G$. thermoleovorans group were classified on the phylum Firmicutes, class Bacilli, ordo Bacillalea and genus Geobacillus. According to Myung-Ji et al. (2012), Firmicutes were the minor groups of microbial diversity in Likupang Marine Hydrothermal, North Sulawesi, Indonesia. Only $7.6 \%$ of microbial diversity in Likupang Marine Hydrothermal was Firmicutes. It indicated that the population of $G$. thermoleovorans was low so that it was difficult to isolate from Likupang Marine Hydrothermal. Therefore, L3 and L9 would be re-cultured and stored as potential bacterial stock.

Amylase-producing Geobacillus sp. was also successfully isolated from sub-seafloor sediments (Jiang 2015). G. kaustrophilus, G. thermoleovorans, and G. toebii were the amylase-producing thermophilic bacteria with the optimal amylase activities at $90^{\circ} \mathrm{C}$ and $\mathrm{pH}$ 7.0. The amylase activity was not detected at a temperature less than $40^{\circ} \mathrm{C}$ which pointed to its thermophilic nature. Sharma et al. (2015) reported that pre-incubation of the enzyme at $100^{\circ} \mathrm{C}$ increase amylase activity. Ardhi et al. (2020) reported that amylase-producing thermophilic Bacillus licheniformis isolated from Bukit Gadang Hot Spring, West Sumatra, Indonesia was able to produce $231.33 \mathrm{U}$ amylase/mL, with the enzyme-specific activity of 101.79 $\mathrm{U} / \mathrm{mg}$ protein at the incubation time of $36 \mathrm{~h}$. The molecular weight of $\alpha$-amylase from $G$. thermoleovorans was estimated to be $58 \mathrm{kDa}$ by SDS-PAGE and very active in a wide range of $\mathrm{pH}$ from $4.0-10.0$. The temperature of $70^{\circ} \mathrm{C}$ was considered as the optimum temperature of the enzyme and distinct thermostability in the presence of $\mathrm{Ca}^{2+}$, retaining $50 \%$ of its initial activity after $90 \mathrm{~h}$ at $70^{\circ} \mathrm{C}$ (Finore et al. 2011).

Thermostable enzymes have provided considerable benefits in the industry because the enzymes have several advantages (Frock and Kelly 2012; Keller et al. 2014). B. subtilis, B. stearothermophilus, B. licheniformis, and B. amyloliquefaciens are recognized as good producers of thermostable $\alpha$-amylase, and have been widely used in commercial industries for various applications (Prakash and Jaiswal 2010). Additionally, thermostable amylases of B. stearothermophilus and B. licheniformis were used in starch processing industries (Gomes et al. 2003; Oziengbe and Onilude 2012) while B. subtilis was applied in food waste biodegradation (Msarah et al. 2020).

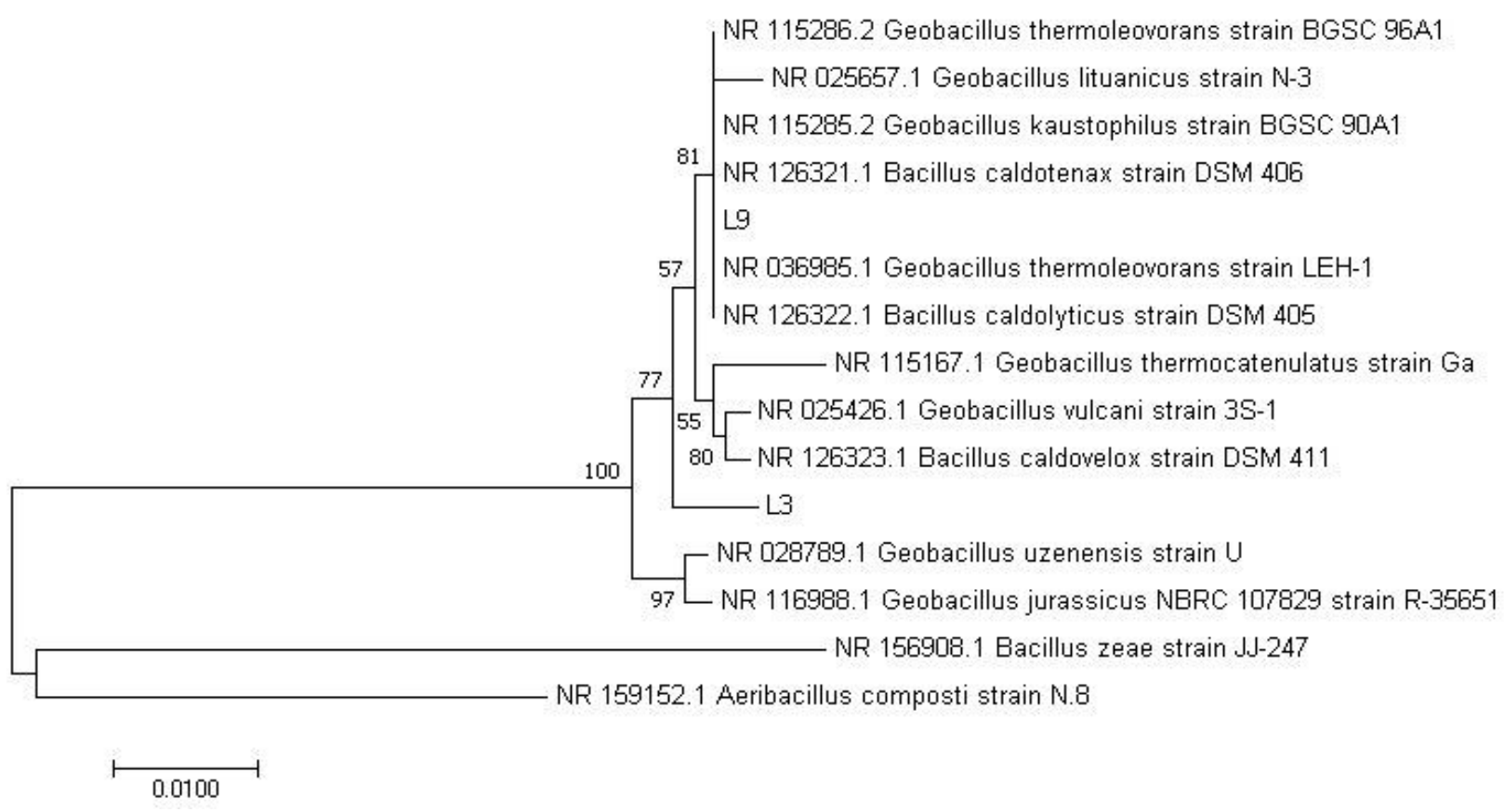

Figure 4. Phylogenetic tree from analysis of 16S rRNA gene sequence of bacterial strain showing the evolutionary relationship of the bacterial isolates within previously characterized species. Bacillus zaea and Aeribacillus composti were used as the 'outgroup'. GenBank accession numbers of $16 \mathrm{~S}$ rRNA sequences are shown in the front. Bootstraps values expressed as a percentage of 1,000 resamplings of the neighbor-joining dataset were set up to estimate the reliability of phylogenetic tree reconstruction 
The search for novel amylase-producing thermophilic bacteria as novel sources of thermostable enzymes was interesting and important to be done. Results of this study showed that Bacillus sp. strain L3 and B. caldotenax strain L9 were thermophilic amylolytic bacteria that were successfully isolated from Likupang Marine Hydrothermal, North Sulawesi, Indonesia with the potential of thermostable amylase producers. These bacterial strains have the potential as thermostable amylase producers with the promising biotechnological application such as starch processing industries. Moreover, the information on thermostable amylase from $B$. caldotenax bacteria was not yet available.

\section{ACKNOWLEDGEMENTS}

The authors are grateful to the Indonesian Ministry of Research and Technology (Kemenristek) and Sam Ratulangi University, Manado, Indonesia that have provided funding for this study.

\section{REFERENCES}

Akihary CV, Kolondam BJ. 2020. Pemanfaatan gen 16s rrna sebagai perangkat identifikasi bakteri untuk penelitian-penelitian di Indonesia. Pharmacon 9 (1): 16-22. DOI: 10.35799/pha.9.2020.27405. [Indonesian]

Aliyu H, Lebre P, Blom J, Cowan D, De Maayer P. 2016. Phylogenomic reassessment of the thermophilic genus Geobacillus. Syst Appl Microbiol 39: 527-533. DOI: 10.1016/j.syapm.2016.09.004.

Ardhi A, Sidauruk AN, Suraya N, Pratiwi NW, Pato U, Saryono. 2020. Molecular identification of amylase-producing thermophilic bacteria isolated from Bukit Gadang Hot Spring, West Sumatra, Indonesia. Biodiversitas 21 (3): 994-1000. DOI: 10.13057/biodiv/d210319.

Charbonneau DM, Meddeb-Mouelhi F, Boissinot M, Sirois M, Beauregard M. 2012. Identification of thermophilic bacterial strains producing thermotolerant hydrolytic enzymes from manure compost. Indian J Microbiol 52 (1): 41-47. DOI: 10.1007/s12088-011-0156-8.

Cihan AC, Tekin N, Ozcan B, Cokmus C. 2012. The genetic diversity of genus Bacillus and the related genera revealed by 16s rRNA gene sequences and ardra analyses isolated from geothermal regions of Turkey. Braz J Micribiol, 43: 309-324. DOI: 10.1590/S1517838220120001000037

De Souza PM, Magalhaes PO. 2010. Application of microbial $\alpha$-amylase in industry: A review. Braz J Microbiol 41: 850-861. DOI: 10.1590/S1517-83822010000400004.

Dinsdale AE, Halket G, Coorevits A, Van Landschoot A, Busse H-JB, De Vos P, Logan NA. 2011. Emended descriptions of Geobacillus thermoleovorans and Geobacillus thermocatenulatus. Int J Syst Evol Microbiol. 61: 1802-1810. DOI: 10.1099/ijs.0.025445-0.

Finore I, Kasavi C, Poli A, Romano I, Oner ET, Kirdar B, Dipasquale L, Nicolaus B, Lama L. 2011. Purification, biochemical characterization and gene sequencing of a thermostable raw starch digesting $\alpha$ amylase from Geobacillus thermoleovorans subsp. stromboliensis subsp. nov. World J Microbiol Biotechnol 27: 2425-2433. DOI: $10.1007 / \mathrm{s} 11274-011-0715-5$.

Frock AD, Kelly RM. 2012. Extreme thermophiles: moving beyond single-enzyme biocataysis. Curr Opin Chem Eng 1: 363-372. DOI: 10.1016/j.coche.2012.07.003.

Gazali FM, Ananda M, Suwastika IN. 2018. Characterization of $\alpha$ amylase activity from thermophilic bacteria isolated from Bora Hot spring, Central Sulawesi. Natural Science: Journal of Science and Technology 7 (1): 99-109. [Indonesian]

Gazali FM, Suwastika IN. 2018. Thermostable $\alpha$-amylase activity from thermophilic bacteria isolated from Bora Hot Spring, Central Sulawesi. J. Phys.: Conf. Ser. 979. The 2nd International Conference on Science (ICOS), Makasar, 2-3 November 2017. DOI: 10.1088/1742-6596/979/1/012001.

Ginting EL, Kemer K, Wullur S, Uria AR. 2019. Identification of proteolytic thermophiles from Moinit coastal hot-spring, North Sulawesi, Indonesia. Geomicrobiol J 37 (1): 50-58. DOI: 10.1080/01490451.2019.1662524.

Gomes I, Gomes J, Steiner W. 2003. Highly thermostable amylase and pullulanase of the extreme thermophilic eubacterium Rhodothermus marinus: production and partial characterization. Bioresour Technol 90: 207-214. DOI: 10.1016/s0960-8524(03)00110-x

Gugliandolo C, Lentini V, Spano A, Maugeri TL. 2012. New bacilli from shallow hydrothermal vents of Panarea Island (Italy) and their biotechnological potential. J Appl Microbiol 112: 1102-1112. DOI: 10.1111/j.1365-2672.2012.05272.x

Jiang T, Menghao MC, Huang M, He H, Lu J, Zhou X, Zhang Y. 2015. Characterization of a thermostable raw-starch hydrolyzing a-amylase from deep-sea thermophile Geobacillus sp. Protein Expr Purif 114: 15-22. DOI: 10.1016/j.pep.2015.06.002.

Kambourova M. 2018. Thermostable enzymes and polysaccharides produced by thermophilic bacteria isolated from Bulgarian hot springs. Eng Life Sci 18:758-767. DOI: 10.1002/elsc.201800022.

Keller M, Loder AJ, Basen M, Izquierdo J, Kelly RM, Adams MW. 2014. Production of lignofuels and electrofuels by extremely thermophilic microbes. Biofuels 5: 499-515. DOI: 10.1080/17597269.2014.996729.

Kumar S, Stecher G, Tamura K. 2016. MEGA7: molecular evolutionary genetics analysis version 7.0 for bigger datasets. Mol Biol Evol 33:1870-1874. DOI: 10.1093/molbev/msw054.

Luang-In V, Yotchaisarn M, Saengha W, Udomwong P, Deeseenthum S, Maneewan K. 2019. Isolation and identification of amylase-producing bacteria from soil in Nasinuan Community Forest, Maha Sarakham, Thailand. Biomed Pharmac J 12: 1061-1068. DOI: $10.13005 / \mathrm{bpj} / 1735$.

Mohammad BT, Al Daghistani HI, Jaouani A, Abdel-Latif S, Kennes C. 2017. Isolation and characterization of thermophilic bacteria from Jordanian Hot Springs: Bacillus licheniformis and Thermomonas hydrothermalis isolates as potential producers of thermostable enzymes. Int J Microbiol 2017: 1-12. DOI: 10.1155/2017/6943952.

Msarah MJ, Ibrahim I, Hamid AA, Aqma WS. 2020. Optimisation and production of alpha amylase from thermophilic Bacillus spp. and its application in food waste biodegradation. Heliyon 6: 1-9. DOI: 10.1016/j.heliyon.2020.e04183.

Myung-Ji S, Kim J, Pyun Y. 2012. 16S rRNA Gene sequence-based microbial diversity analyses of the geothermal areas of Cisolok, Kamojang, and Likupang in Indonesia. Korean $\mathrm{J}$ Microbiol Biotechnol 40 (3): 268-273. DOI: 10.4014/kjmb.1205.05001.

Nazina T, Tourova T, Poltaraus A, Novikova E, Grigoryan A, Ivanova A, Lysenko A, Petrunyaka V, Osipov G, Belyaev S, Ivanov M. 2001. Taxonomic study of aerobic thermophilic bacilli: descriptions of Geobacillus subterraneus gen. nov., sp. nov.and Geobacillus uzenensis sp. nov. from petroleum reservoirs and transfer of Bacillus stearothermophilus, Bacillus thermocatenulatus, Bacillus thermoleovorans, Bacillus kaustophilus, Bacillus thermoglucosidasius and Bacillus thermodenitrificans to Geobacillus as the new combinations $G$. stearothermophilus, G. thermocatenulatus, $G$. thermoleovorans, $G$. kaustophilus, $G$. thermoglucosidasiusand, G. thermodenitrificans. Int J Syst Evol Microbiol 51 (2): 433-446. DOI: 10.1099/00207713-51-2-433.

Nazina TN, Sokolova DS, Grigoryan AA, Shestakova NM, Mikhailova EM, Poltaraus AB. 2005. Geobacillus jurassicus sp. nov., a new thermophilic bacterium isolated from a high-temperature petroleum reservoir, and the validation of the Geobacillus species. Syst Appl Microbiol 28: 43-53. DOI: 10.1016/j.syapm.2004.09.001.

Nguyen QD, Rezessy-Szabó JM, Claeyssens M, Stals I, Hoschke A. 2002. Purification and characterization of amylolytic enzymes from thermophilic fungus Thermomyces lanuginosus strain ATCC 34626. Enzyme Microb Technol 31 (3): 345-52. DOI: 10.1016/S01410229(02)00128-X.

Nihaya I, Sarjono PR, Aminin ALN. 2013. Studi filogeni dan uji potensi antibakteri serta enzim ekstraseluler isolat Geobacillus sp. dari sumber air panas Gedongsongo. J Kim Sains Apl 16: 38-41. DOI: 10.14710/jksa.16.2.38-41. [Indonesian]

Oziengbe EO, Onilude AA. 2012. Production of a thermostable $\alpha$-amylase and its assay using Bacillus licheniformis isolated from excavated 
land sites in Ibadan, Nigeria. Bajopas 5 (1): 132-138. DOI: 10.4314/bajopas.v5i1.24.

Poletto TV, Vieira CRW, Silva CP, Fracalossi DM. 2018. Isolation and identification of a potential amylolytic probiotic bacterium from the gut of Jundiá catfish. Rhamdia Quelen Braz Arch Biol Technol 61: 19. DOI: $10.1590 / 1678-4324-2018161205$

Prakash O, Jaiswal N. 2010. Alpha-amylase: An ideal representative of thermostable enzymes. Appl Biochem Biotechnol 160: 2401-2414. DOI: $10.1007 / \mathrm{s} 12010-009-8735-4$.

Raddadi N, Cherif A, Daffonchio D, Neifar M, Fava F. 2015 Biotechnological applications of extremophiles, extremozymes and extremolytes. Appl Microbiol Biotechnol 99 (19): 7907-7913. DOI: 10.1007/s00253-015-6874-9.

Satrimafitrah P, Razak AR, Hardi J, Puspitasari DJ, Yelenggete I, Rafik. 2020. Thermostable amylase activity produced by thermophilic bacteria isolated from Pulu Hotspring, Central Sulawesi. J. Phys.: Conf. Ser. 1434. National Seminar on Physics, Palu, 28 September 2019. DOI: $10.1088 / 1742-6596 / 1434 / 1 / 012034$.

Sharma P, Gupta S, Sourirajan A, Dev K. 2015. Characterization of extracellular thermophilic amylase from Geobacillus sp. isolated from Tattapani Hot Spring of Himachal Pradesh, India. Curr Biotechnol 4 (2): 202-209. DOI: 10.2174/2211550104666150612223748.

Singh G, Bhalla A, Kaur P, Capalash N, Sharma P. 2011. Laccase from prokaryotes: A new source for an old enzyme. Rev Environ Sci Biotechnol 10: 309-326. DOI: 10.1007/s11157-011-9257-4
Thairu Y, Nasir IA, Usman Y. 2014. Laboratory perspective of Gram staining and its significance in investigations of infectious diseases. SSAJM 1: 168-174. DOI: 10.4103/2384-5147.144725.

Wantania LL, Wullur S, Ginting EL, Mantiri DM, Undap SL, Sumilat DA, Gerung GS. 2019. Isolation and amplification of 16S rRNA gen of associated microbial isolates in red algae Kappaphycus alvarezii from Belang, Southeast Minahasa Regency, North Sulawesi. Jurnal Ilmiah Platax 7 (1): 220-226. DOI: 10.35800/jip.7.1.2019.22808 [Indonesian]

Wullur S, Napitupulu H, Wantania LL, Ginting EL, Warouw V, Tilaar SO, Tallei TE, Rumengan IFM. 2020. Molecular identification of bacteria isolated from culture medium of rotifer fed on fishery waste diet. Biodiversitas 21 (6): 1735-1740. DOI: 10.13057/biodiv/d210649.

Zeigler DR. 2005. Application of a recN sequence similarity analysis to the identification of species within the bacterial genus Geobacillus. Intl J Syst Evol Microbiol 55: 1171-1179. DOI: 10.1099/ijs.0.634520 .

Zhang RY, Bin Z, Yan YW, Jeon CO, Li M, Cai M, Quan ZX. 2020. Design of targeted primers based on 16S rRNA sequences in metatranscriptomic datasets and identification of a novel taxonomic group in the Asgard archaea. BMC Microbiol 20: 1-10. DOI: 10.1186/s12866-020-1707-0. 